\title{
Predation Rate of Spodoptera frugiperda (Lepidoptera: Noctuidae) Larvae With and Without Defense by Podisus nigrispinus (Heteroptera: Pentatomidae)
}

\author{
José Cola Zanuncio ${ }^{1 *}$, Carlos Alberto Domingues da Silva ${ }^{1,2}$, Eraldo Rodrigues de Lima ${ }^{1}$, \\ Fabrício Fagundes Pereira ${ }^{1}$, Francisco de Souza Ramalho ${ }^{2}$ and José Eduardo Serrão ${ }^{3}$ \\ ${ }^{1}$ Departamento de Biologia Animal; ${ }^{3}$ Departamento de Biologia Geral; Universidade Federal de Viçosa; Campus \\ Universitário; zanuncio@ufv.br; jeserrao@ufv.br; 36571-000; Viçosa - MG - Brasil. ${ }^{2}$ Embrapa; Centro Nacional \\ de Pesquisa de Algodão; C. P. 174; cads@insecta.ufv.br; 58107-720; Campina Grande - PB - Brasil
}

\begin{abstract}
The effect of the defense of the prey Spodoptera frugiperda (J.E. Smith) (Lepidoptera: Noctuidae) on predation rates of Podisus nigrispinus (Dallas) (Heteroptera: Pentatomidae) females was studied. P. nigrispinus preyed 1.0, 1.4, 1.2, 3.8 and 3.0 and 0.4, 0.8, 1.6, 2.8 and 3.2 third instars of S. frugiperda larvae with and without defense, respectively, with the densities of one, two, four, six and eight larvae. The attack rate and the manipulation time were, respectively, $0.67 \pm 0.39^{-h}$ and $6.72 \pm 2.88$ for $\mathrm{P}$. nigrispinus females fed with larvae with defense and $2.51 \pm$ $0.16^{-h}$ and $0.51 \pm 0.77 \mathrm{~h}$ for those without defense. The functional response of the predator $\mathrm{P}$. nigrispinus varies with the defense and the density of the prey $\mathrm{S}$. frugiperda, with larger consumption of prey without defense at higher densities.
\end{abstract}

Key words: Asopinae, biological control, predator, functional response

\section{INTRODUCTION}

Spodoptera frugiperda (J.E. Smith) (Lepidoptera: Noctuidae) is a polyphagous caterpillar damaging plants of economic importance such as, corn, wheat, rice, bean, peanut, tomato, potato, cabbage, spinach, pumpkin, collard greens and cotton (Cruz et al., 1999). The control of this pest presents problems, mainly, with the introduction of corn plantation in the winter in regions where irrigation infrastructure is adequate. Spodoptera frugiperda can attack corn plants at any time of the year and, for this reason, the frequency and intensity of the use of insecticides such as pirethroids and organophosphates has led to failures on the control of this pest (Diaz-Rodriguez and Omoto, 2001).

The biological control represents an important strategy to reestablish the biodiversity of agricultural agroecossystems, especially with the introduction of entomophagous organisms with classic innoculative techniques or the increase of natural populations of predators, parasitoids and pathogens (Silva, 2000).

The generalist predator Podisus nigrispinus (Dallas) (Heteroptera; Pentatomidae) is widespread in the Neotropical region (Thomas, 1992) where it has been reported feeding on Lepidoptera pests such as $S$. frugiperda larvae (Batalha et al., 1997; Zanuncio et al., 1998). This

* Author for correspondence 
showed that this predator could be used in programs of biological control of $S$. frugiperda, making important to determine its control potential against this pest.

Predators play an important role in the maintenance of the aggressiveness and the energy of the preys by eliminating those with lower defense capacity while the ones with better aptitude can survive and reproduce (Price, 1975). For this reason, these natural enemies act as agents for the evolution of the prey by selecting stronger and vigorous individuals. On the other hand, the predators develop more efficient techniques to attack their preys (Azevedo and Ramalho, 1999a, b; Lemos et al., 2005). Factors such as the densities of the prey and predators, environmental conditions, mechanisms of prey defense and strategies of attack of the predator can interfere in the predation process (Holling, 1959). Therefore, the knowledge of the effects of prey defense on the functional response of predators is important to understand the mechanisms involved in the system of co-evolution predator-prey.

The objective of this study was to determine the predation rate of $P$. nigrispinus in $S$. frugiperda larvae with and without defense.

\section{MATERIAL AND METHODS}

The experiment was developed in the laboratory of Biological Control of Insects of the Federal University of Viçosa (UFV) in the Municipality of Viçosa, State of Minas Gerais, Brazil at $25 \pm 1^{\circ} \mathrm{C}$, $68 \pm 10 \%$ relative humidity and 12 hours photo phase. Specimens of the predator $P$. nigrispinus and of the prey $S$. frugiperda were obtained from the Institute of Applied Biotechnology to Agriculture (BIOAGRO) reared according to Zanuncio et al. (1994) and fed diet of Shorey and Hale (1965), respectively. A total of 300 eggs of $S$. frugiperda were selected and put in Petri dishes with paper filter until hatching of the caterpillars, which were fed with corn leaves up to the third instar. Five days old newly mated $P$. nigrispinus females were individualized in an experimental arena and starved for $24 \mathrm{~h}$. The experimental arena consisted of a plastic cylinder $(8 \mathrm{~cm}$ high, $14 \mathrm{~cm}$ in diameter), the top of which was covered by a plastic Petri dish. After this period, a total of one, two, four, six or eight third instars $S$. frugiperda larvae, with or without defense, were transferred per arena with five replications. The larvae without defense were, partially, immobilized with $0.15 \mathrm{~mm}$ entomological pins, inserted in the ventral part of their mesothorax (Silva et al., 1996). All the insects were weighed before starting the study. The statistical analysis was accomplished with the R Statistical System (Ihaka and Gentleman, 1996) (http://termix.ufv.br/CRAN). The regression analyses were used to determine the type of functional response and to compare the predation rate of $P$. nigrispinus females with several densities and with or without defense of $S$. frugiperda larvae. The sign of the linear coefficient estimated with the regression logistics (negative or positive) can be used to distinguish the shape of the curve of the functional response (types II or III, respectively) (Trexler et al., 1988; De Clercq et al., 2000). The attack rate (a) and the manipulation time (Th), used to establish the equation of the functional response, were determined after its linearization according to Woolf $(\mathrm{Nt} / \mathrm{Na}=\mathrm{Th} \mathrm{Nt}+\mathrm{a}-1)$ (Currie 1982, Fan and Petitt, 1994). Therefore, the manipulation period of prey (Th) can be determined with simple linear equation by plotting the data of $\mathrm{Nt} / \mathrm{Na}$ versus $\mathrm{Nt}$ $(\ddot{y}=a+b x)$ and multiplying the total exposition time (T) by the angular coefficient of this straight line (b). The attack rate (a) corresponds to the intercept of the straight line (1/a) (Fan and Petitt, 1994).

\section{RESULTS}

The survival of $S$. frugiperda larvae was higher than the $98 \%$ in the absence of the predator what did not make necessary to correct these data. The average weight of larvae of this prey and of females of the predator $P$. nigrispisnus was 113.47 $\pm 44.68 \mathrm{mg}$ and $65.40 \pm 12.14 \mathrm{mg}$, respectively. Each P. nigrispinus female preyed 1.0, 1.4, 1.2, 3.0 and $3.8 \mathrm{~S}$. frugiperda larvae with defense and $0.4,0.8,1.6,2.8$ and 3.2 larvae without defense with the densities of one, two, four, six and eight larvae per arena. The high predation rates were observed in the densities of six and eight larvae per arena, with and without defense, respectively. The density and the interaction density versus prey defense were significant, but the effect of the prey defense was not observed separately (Table 1). The number of $S$. frugiperda larvae preyed by $P$. nigrispinus female showed an increase tendency at all densities (Fig. 1). The regression curves fitted 
for S. frugiperda larvae with and without defense showed different functional responses (Fig. 1).

The attack rate (a) and the manipulation time (Th) of S. frugiperda larvae with defense (Table 2) were $0.67 \pm 0.39^{-\mathrm{h}}$ and $6.72 \pm 2.88 \mathrm{~h}$. These values were lower than the attack rate (a) of $2.51 \pm 0.16^{\text {-h }}$ and larger than the manipulation time (Th) of 0.51 \pm 0.77 hours for larvae without defense.

\section{DISCUSSION}

Podisus nigrispinus presented a functional response of type II (Holling, 1961) with S. frugiperda (Hübner) larvae with defense. This was similar to that reported for the females of this predator with larvae of Spodoptera exigua Hübner and Chrysodeixis chalcites (Esper) (Lepidoptera: Noctuidae) (De Clercq et al., 1998; Mohaghegh et al., 2001). Podisus nigrispinus presented a type I functional response (Holling, 1961) with $S$. frugiperda larvae without defense. This response was considered a theoretical model because the number of individuals preyed increased linearly with their density (Van den Bosch et al., 1982). This indicated that the model of the functional response presented by $P$. nigrispinus could be influenced by the lowest defense capacity of $S$. frugiperda larvae immobilized with pins. Substandard individuals were captured disproportionately when the type of prey was difficult to capture but not when it was easy to capture (Krebs, 2001).

The functional response of $P$. nigrispinus was affected by the defense of $S$. frugiperda larvae at the same density. This could be explained by the different values of intercepts of the regression curves and it demonstrated that the defense of the prey when at low densities had low impact on predation rates by $P$. nigrispinus. Defenses of phytophagous insects include behavioral pattern, chemistry, morphologic and physiologic traits that are effective against natural enemies (Witz, 1990, Gross, 1991, Dyer, 1995). Podisus nigrispinus can select prey with minor potential defense in conditions of abundance of them which can reduce unnecessary expenses of energy. Podisus maculiventris (Say) (Heteroptera: Pentatomidae) selected fifth instar larvae according to their capacity of defense with different manipulation time and preyed larger number of larvae without defense (Morris, 1963). This was demonstrated also for the predator Supputius cincticeps (Stäl) (Heteroptera: Pentatomidae) with growth rates, rates of daily and total relative consumption, efficiency of food conversion and weight depending on the defense of the preys and also on the temperature (Azevedo and Ramalho, 1999a,b). This showed that the knowledge of the defense mechanisms of the prey is important and it can be used, isolated or combined, with attributes of this predator such as reproductive capacity and searching rate and density-dependence to define release techniques.

Table. 1 - Variance analysis of the effect of the density (D) and defense (DP) of Spodoptera frugiperda (Lepidoptera: Noctuidae) larvae on preying rates of Podisus nigrispinus (Heteroptera: Pentatomidae) females

\begin{tabular}{lcccc}
\hline Variation source & DF & Deviance & F & P \\
\hline Density (D) & 1 & 3.08 & 44.849 & $0.000^{* * *}$ \\
Prey defense (DP) & 1 & 0.05 & 0.820 & 0.400 \\
D x DP & 1 & 0.47 & 6.855 & $0.039^{*}$ \\
\hline
\end{tabular}

\begin{tabular}{lllll}
\hline Residue & 6 & 0.48 & -
\end{tabular}

${ }^{(*)}$ Significant $(\mathrm{P}<0.05)$

${ }^{(* * *)}$ Significant $(\mathrm{P}<0.001)$

Table. 2 - Effect of the defense of the prey on the attack rate (a) and manipulation time (Th) of Podisus nigrispinus (Heteroptera: Pentatomidae) females on third instars of Spodoptera frugiperda (Lepidoptera: Noctuidae) larvae

\begin{tabular}{lcc}
\hline Parameter & With defense & Without defense \\
\hline $\mathrm{a}\left(\mathrm{h}^{-1}\right)$ & $0.67 \pm 0.39$ & $2.51 \pm 0.16$ \\
$\mathrm{~T}_{\mathrm{h}}(\mathrm{h})$ & $6.72 \pm 2.88$ & $0.51 \pm 0.77$ \\
\hline
\end{tabular}




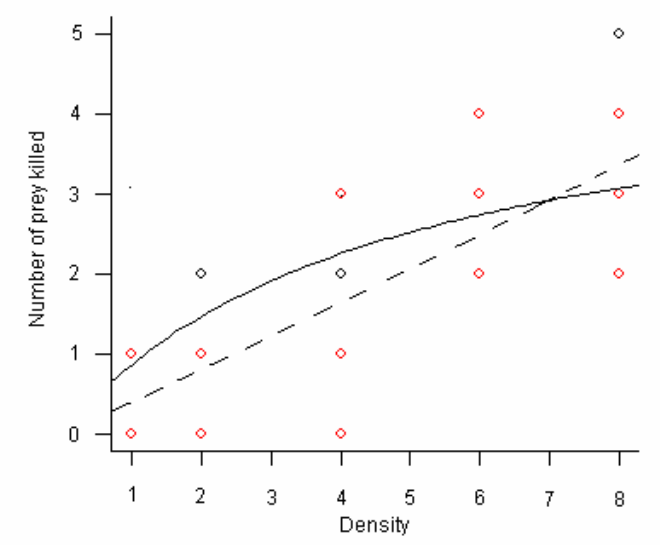

Figure 1 - Functional response of Podisus nigrispinus (Heteroptera: Pentatomidae) as function of the density of Spodoptera frugiperda (Lepidoptera: Noctuidae) with (O, solid line) or without defense $(\mathrm{O}$, broken line).

The high attack rates (a) and the lower manipulation time (Th) of $P$. nigrispinus on $S$. frugiperda larvae without defense, suggested that defense movements of the prey favor its finding by predators, but they could hinder their manipulation by these natural enemies. The attack rate (a) and the manipulation time (Th) of third instars of $S$. frugiperda larvae with defense by $P$. nigrispinus had higher values than those for this predator preying third instar S. exigua larvae (Mohaghegh et al., 2001). For this reason, the attack rate and the manipulation time of this predator could depend on the defense and prey used.

To conclude, functional response of the predator $P$. nigrispinus varied with the defense and the density of the prey $S$. frugiperda, with larger consumption of preys without defense when they were at high densities.

\section{ACKNOWLEDGEMENTS}

We thank to the Brazilian agencies "Conselho Nacional de Desenvolvimento Científico e Tecnológico (CNPq)", "Coordenação de Aperfeiçoamento de Pessoal de Nível Superior (CAPES)" and "Fundação de Amparo à Pesquisa do Estado de Minas Gerais (FAPEMIG)" for financial support.

\section{RESUMO}

Objetivou-se determinar o efeito da defesa da presa Spodoptera frugiperda (J.E. Smith) (Lepidoptera: Noctuidae) na taxa de predação por fêmeas de Podisus nigrispinus (Dallas) (Heteroptera: Pentatomidae). Podisus nigrispinus, predou 1,$0 ; 1,4 ; 1,2 ; 3,8 ; 3,0$ lagartas de terceiro estádio de $S$. frugiperda com defesa, respectivamente, nas densidades de uma, duas, quatro, seis e oito lagartas, enquanto esses valores foram de 0,$4 ; 0,8 ; 1,6 ; 2,8 ; 3,2$ lagartas sem defesa, respectivamente, nessas densidades. A taxa de ataque $(a)$ e o tempo de manipulação $\left(\mathrm{T}_{\mathrm{h}}\right)$ foram, respectivamente, de $0,67 \pm 0,39^{-\mathrm{h}}$ e $6,72 \pm 2,88$ horas para fêmeas de $P$. nigrispinus alimentadas com lagartas com defesa e de $2,51 \pm 0,16^{\text {-h }}$ e 0,51 $\pm 0,77$ horas para aquelas sem defesa. A resposta funcional do predador $P$. nigrispinus varia com a defesa e a densidade da presa $S$. frugiperda, com maior consumo de presas sem defesa em altas densidades.

\section{REFERENCES}

Azevedo, R.F. and Ramalho, F.S. (1999a), Efeitos da temperatura e da defesa da presa no consumo pelo predador Supputius cincticeps (Stäl) (Heteroptera: Pentatomidae). Pesquisa Agropecuária Brasileira. 34: 165-171. 
Azevedo, R.F. and Ramalho, F.S. (1999b), Efeitos da temperatura e da defesa da presa na utilização de Tenebrio molitor L. por ninfas do predador Supputius cincticeps (Heteroptera: Pentatomidae). Anais da Sociedade Entomológica do Brasil. 28: 111-119.

Batalha, V.C., Zanuncio, J.C.; Picanço, M. and Guedes, R.N.C. (1997), Selectivity of insecticides to Podisus nigrispinus (Heteroptera: Pentatomidae) and its prey Spodoptera frugiperda (Lepidoptera: Noctuidae). Ceiba. 38: 19-22.

Cruz, I.; Figueiredo, M.L.C. and Matosos, M.J. (1999), Controle biológico de Spodoptera frugiperda utilizando o parasitóide de ovos Trichogramma. Circular Técnica. Sete Lagoas: EMBRAPA-CNPMS. 40p.

Currie, D.J. (1982), Estimating Michaelis-Menten parameters: Bias, variance, and experimental design. Biometrics. 38: 907-919.

De Clercq, P.; Merlevede, F.; Mestdagh, I.; Vandendurpel, K.; Mohaghegh, J. and Degheele, D. (1998), Predation on the tomato looper Chrysodeixis chalcites (Esper) (Lep. Noctuidae) by Podisus maculiventris (Say) and Podisus nigrispinus (Dallas) (Het., Pentatomidae). Journal of Applied Entomology, 122: 93-98.

De Clercq, P.; Mohaghegh, J. and Tirry, L. (2000), Effect of host plant on the functional response of the predator Podisus nigrispinus (Heteroptera: Pentatomidae). Biological Control, 18: 65-70.

Diaz-Rodriguez, G.I. and Omoto, C. (2001), Herança da resistência de Spodoptera frugiperda (J.E. Smith) (Lepidoptera: Noctuidae) a lambda-cialotrina. Neotropical Entomology, 30: 311-316.

Dyer, L.A. (1995), Tasty generalists and nasty specialists? A comparative study of antipredator mechanisms in tropical lepidopteran larvae. Ecology, 76: 1483-1496.

Fan, Y. and Petitt, F.L. (1994), Parameter estimation of the functional response. Environmental Entomology, 23: 785-794.

Gross, P. (1991), Influence of target pest feeding niche on success rates in classical biological control. Environmental Entomology, 20: 1217-1227.

Holling, C.S. (1959), Some characteristics of simple types of predation and parasitism. Canadian Entomologist, 91: 385-398.

Holling, C.S. (1961), Principles of insect predation. Annual Review of Entomology, 6:163-182.

Ihaka, R. and Gentleman, R. (1996), R: a language for data analysis and graphics. Journal of Computer Statistics, 5: 299-314.

Krebs, C.J. 2001. Ecology: the experimental analysis of distribution and abundance. Addison Wesley Longman, Inc., San Francisco. 695p.
Lemos, W.P., Zanuncio, J.C. and Serrão, J.E. (2005), Attack behavior of Podisus rostralis (Heteroptera: Pentatomidae) adults on caterpillars of Bombyx mori (Lepidoptera: Bombycidae). Brazilian Archives of Biology and Technology, 48: 975-981.

Mohaghegh, J., De Clercq, P. and Tirry, L. (2001), Functional response of the predators Podisus maculiventris (Say) and Podisus nigrispinus (Dallas) (Het., Pentatomidae) to the beet armyworm, Spodoptera exigua (Hübner) (Lep., Noctuidae): effect of temperature. Journal of Applied Entomology, 125: 131-134.

Morris, R.F. (1963), The effect of predator age and prey defense on functional response of Podisus maculiventris (Say) to the density of Hypantria cunea Drury. Canadian Entomologist, 95: 1009-1020.

Price, P.W. (1975), Insect Ecology. John Willey and Sons, New York, 514p.

Shorey, H.H. and Hale, R.L. (1965), Mass-rearing of the larvae of nine noctuid species on a simple artificial medium. Journal of Economic Entomology, 58: 522-524.

Silva, C.A.D. (2000), Microorganismos entomopatogênicos associados a insetos e ácaros do algodoeiro. Documentos. Campina Grande: EMBRAPA-CNPA. 77, 45p.

Silva, E.N.; Santos, T.M. and Ramalho, F.S. (1996), Desenvolvimento ninfal de Supputius cincticeps Stäl (Hemiptera: Pentatomidae) alimentado com curuquerê do algodoeiro. Anais da Sociedade Entomológica do Brasil, 25: 103-108.

Thomas, D.B. (1992), Taxonomic synopsis of the Asopinae Pentatomidae (Heteroptera) of the western hemisphere. The Thomas Say Foundation. Lanham: Entomological Society of America, v.16.

Trexler, J.C.; Mcculloch, C.E. and Travis, J. (1988), How can the functional response best be determine? Oecologia, 76: 206-214.

Van den Bosch, R.; Messenger, P.S. and Gutierrez, A.P. (1982), An introduction to biological control. Plenum Press, New York. 246p.

Witz, B.W. (1990), Antipredator mechanism in arthropods: a twenty-year literature survey. Florida Entomologist, 73: 71-99.

Zanuncio, J.C.; Alves, J.B.; Zanuncio, T.V. and Garcia, J.F. (1994), Hemipterous predator of eucalypt defoliator caterpillars. Forest Ecology and Management, 65: 65-73.

Zanuncio, J.C.; Batalha, V.C.; Guedes, R.N.C. and Picanço, M. (1998), Insecticide selectivity to Supputius cincticeps (Stal) (Het.: Pentatomidae) and its prey Spodoptera frugiperda (J.E. Smith) (Lep.: Noctuidae). Journal of Applied Entomology, 122: 457-460. 